University of Rhode Island

DigitalCommons@URI

2018

\title{
Assessing Political Participation on the Internet in Contemporary China
}

Ping Xu

University of Rhode Island, pingxu@uri.edu

Yinjiao Ye

University of Rhode Island, yinjiao_ye@uri.edu

Mingxin Zhang

Follow this and additional works at: https://digitalcommons.uri.edu/psc_facpubs

The University of Rhode Island Faculty have made this article openly available.

Please let us know how Open Access to this research benefits you.

This is a pre-publication author manuscript of the final, published article.

Terms of Use

This article is made available under the terms and conditions applicable towards Open Access

Policy Articles, as set forth in our Terms of Use.

Citation/Publisher Attribution

Ping Xu, Yinjiao Ye \& Mingxin Zhang (2018) Assessing political participation on the Internet in contemporary China, Chinese Journal of Communication, DOI: 10.1080/17544750.2018.1445119

Available at: http://dx.doi.org/10.1080/17544750.2018.1445119

This Article is brought to you for free and open access by the Political Science at DigitalCommons@URI. It has been accepted for inclusion in Political Science Faculty Publications by an authorized administrator of DigitalCommons@URI.For more information, please contact digitalcommons-group@uri.edu. 


\title{
Assessing Political Participation on the Internet in Contemporary China
}

\author{
Ping $\mathrm{Xu}^{\mathrm{a}}$, Yinjiao $\mathrm{Ye}^{\mathrm{a}}$, Mingxin Zhang ${ }^{\mathrm{b}}$ \\ ${ }^{\mathrm{a}}$ University of Rhode Island, USA; ${ }^{\mathrm{b}}$ Huazhong University of Science \& Technology, China
}

\begin{abstract}
Drawing on the resource model of political participation, this study examines the ways in which various resources, including money, computer and Internet access, Internet skills, and civic skills predict Chinese citizens' political participation online. The results showed that income was a significant predictor of online political participation regardless of whether it was by using the Internet to contact governmental officials, monitoring public policies online, or participating in online protests. Civic skills also consistently predicted the three forms of online political participation. Computer and Internet access as well as Internet skills were significant predictors of some forms of online political participation but not all of them. Political interest positively moderated the association between income and each of the three dependent variables. The theoretical and empirical implications of these results are discussed.
\end{abstract}

Keywords: resource model of political participation; computer and Internet access; Internet-use skills; civic skills; political interest

Political participation has been defined as "behavior aimed at shaping governmental policy, either by influencing the selection of government personnel or by affecting their choices" (Conover, 1995, cited in Irwin, 2003, p. 29). In western democracies, political participation comprises a wide range of activities, such as holding or running for political office, voting, attending public hearings, writing to legislators, signing a petition, marching in a protest, and serving in political organizations (Conover, 1995; Putnam, 2000).

Political participation in China, however, differs significantly from that in western democracies (Jennings, 1997). There are fewer institutionalized channels for ordinary Chinese citizens to effectively influence either the policy-making process or the selection of governmental officials. In the channels that do exist, citizens can elect and contact people's representatives in the People's Congress regarding policy proposals. They can also file a petition in the form of a letter or personal visit to the Bureau of Letters and Visits (BLV) at the local or central government, and they can mobilize social protests in various forms (Chen, 2004; Chen \& $\mathrm{Xu}, 2011$; Jennings, 1997; Zhang, 2015). However, due to their limited power in policy-making, the BLV and the People's Congress often fail to effectively address and to provide solutions to citizens' specific problems. As a result, citizens tend to shy away from these institutionalized channels. Previous research found that only $10 \%$ to $15 \%$ of Chinese citizens had ever voted in an election for people's representatives from 2003 to 2008 (China Research and Data Center, 2009; $\mathrm{Hu}, 2008$; Wang \& Fang 2010). Although the individual petition is still a popular means of participation, many petitioners quickly find that their cases are ignored by officials in the BLV (Chen, 2004; Li, 2008).

Amid the disappointment and frustration derived from the ineffectiveness of these institutionalized channels in addition to the increasing number of social and economic problems, Chinese citizens desire alternative channels to participate in politics (Gustafsson et al., 2008; 
Yang, 2003; Wedeman, 2005). The Internet has emerged as an alternative arena of participation in China's relatively closed authoritarian regime. The number of Internet users in China increased from 1 million in 1997 to 11 million in 2005 and then to 710 million in 2016 (China Internet Network Information Center [CNNIC], 2016). Because of the relatively low cost, ease of use, and availability of various online tools (e.g., bulletin boards, interactive social media applications, and governmental portal sites), Chinese citizens can contact governmental officials, voice their opinions, form groups, and even mobilize collective actions. A survey of Chinese young adults found that $58 \%$ of the respondents voted online, $43 \%$ participated in online public polls, and $12 \%$ mobilized others online to monitor an event collectively (Lu \& Pan, 2015). A study of college students in China found that $11 \%$ participated in political activities through Weibo (Zhao \& Chen, 2013). In China, it is said that when one faces grievances and seeks a governmental response, "it is more effective to go to the Web than to the BLV" (Tao \& Chen, 1999; Zhang, 2015).

In recent years, numerous cases have emerged in which Chinese citizens successfully used the Internet to influence governmental personnel decisions and public policies and to reveal the corruption and misconduct of governmental officials at local, state, and federal levels. For example, in 2007, when the National Development and Reform Commission decided to build a Paraxylene (PX) chemical plant less than 20 kilometers away from downtown Xiamen in Fujian province, many Xiamen citizens used the Internet to spread the news and to organize protests, eventually exerting enough pressure for the government to abandon the plan (Zhang, 2015). A story about the self-immolation of a three-person family in Jiangxi Province due to the forced confiscation of their house, which was posted on the Chinese microblog Weibo, attracted so much attention in society that it led to the removal of the mayor and party secretary of the county, Yi Huang (Zhang, 2015).

Noting this relatively new phenomenon in China, we based the present study on previous research to examine three forms of online political participation in contemporary China. Previous research on offline political participation in China used surveys to focus on three types of behaviors: voicing behavior (i.e., writing or offering suggestions/opinions to a governmental official); contacting behavior (i.e., contacting a delegate to a local people's congress); and collective behavior (i.e., working with others to solve a social problem) (Jennings, 1997, 1998). Such categorization was framed intentionally to be "compatible with those that have a lengthy lineage in Western surveys" (Jennings, 1997, p. 363). Studies of online political participation in western countries such as the US focused on similar types of activities. For instance, Samuel Best and Brian Krueger (Best \& Krueger, 2005, 2006, 2008; Krueger, 2002), who are well known for their studies of online political participation behavior in the US, focused on whether or not Americans used the Internet (i) to contact an elected representative, government official, or candidate for office to express an opinion about a local, national, or international issue; (ii) to sign an online petition about a local, national, or international issue; (iii) to work with others in an Internet community to try to deal with a local issue or problem. These uses of the Internet mirror Jennings' (1997) categorization of political participation, which includes voicing behavior, contacting behavior, and collective behavior.

Although we adopted the same categorization in our study, we made two adjustments to fit political participation in contemporary China. First, we grouped the offering of suggestions to a governmental official and contacting a people's representative into one category because the National People's Congress is also an institutionalized governmental entity. Second, considering that the Internet provides one of the most powerful tools for Chinese citizens to monitor and 
influence their governmental decisions in contemporary China, we include a category to reflect this important political function of the Internet. In recent years, there has been an increasing trend for ordinary citizens to observe and monitor the making, passing, implementation, revision, and annulment of national and local policies. Chinese netizens not only have used the Internet to reveal corruption and misconducts of governmental officials during the policy implementation stage but also have tried to monitor and influence policies that are pertinent to their daily lives (Fishkin, 2010; He \& Warren, 2011; Peng, Lan, \& Ke, 2004). Because of the emergence and growth of this new participatory behavior as well as its increasing impact on Chinese politics, we include monitoring the governmental policy process in our examination of online political participation. Hence, our study focuses on three forms of online political participation: contacting a government entity; monitoring governmental policy process and behavior; and collective actions. Although there may be further kinds of participatory activities in China, these three forms capture the typical political participation activities that previous researchers have investigated in both China and in the west. We therefore adapt them to describe political participation in contemporary China.

In our study, we also address the issue of the delineation of online and offline political participation. Many scholars in the field have long relied on survey questions to differentiate online and offline participation without conceptually separating the two types of participation (Best \& Krueger, 2005, 2006, 2008; Krueger, 2002). Following previous studies on online political participation in western countries (Best \& Krueger, 2005, 2006, 2008), we asked our respondents whether they had ever used the Internet to (i) give suggestions or express opinions to the government, (ii) monitor governmental policy process or behavior, and (iii) organize or participate in protests. In our study, we define online political participation as using online tools, such as the Internet and social media, to contact government officials, voice opinions to governmental officials, and work with others to solve political problems collectively. Offline political participation is defined as the use of offline tools such as face-to-face meetings and protests to engage in the aforementioned three behaviors. The following section provides a review of the three forms of online political participation and the determinants of online political participation in China.

\section{Online Political Participation in China}

\section{Contacting governmental officials}

In 1998, the Chinese government launched the Government Online project to encourage governmental agencies to create their own websites and to use online administration to enhance their administrative efficiency (Jiang \& Xu, 2009). By 2006, 100\% of provincial governments, $93 \%$ of city governments, and $69 \%$ of county governments had their own portal websites (Jiang $\& \mathrm{Xu}, 2009)$. These websites have gradually become expanded to include various functions, such as the governor's (or mayor's) mailbox, e-petitions, and a citizens' comment box. Almost all provincial portal sites have adopted an online mailbox for citizens to send in their complaints. Some governments have publicized recent complaints received from citizens, and others have even published governmental responses to these complaints. Many of them serve as online channels for citizens to contact their governmental officials (Jiang \& Xu, 2009). In particular, underprivileged Chinese citizens can communicate their grievances to governmental officials using these online tools (Hartford, 2005).

Compared to contacting governmental officials offline, contacting governmental officials online has many advantages and therefore could be much more attractive to ordinary citizens. In 
order to contact a governmental official offline, the citizen has to pay for transportation, go through complex bureaucratic processes in order to meet with the official, and face a high chance of being ignored or receiving no feedback. In contrast, contacting officials online only requires access to the Internet and some Internet skills, and therefore is much less costly and much more efficient. As of 2007, only $7.7 \%$ of more than 100 million Chinese Internet users regularly visited governmental websites. By 2016, the number of online governmental service users had reached 1.76 billion, which comprised $24.8 \%$ of all Internet users. Moreover, $14.6 \%$ of them used the service through governmental Weixin accounts, $6.7 \%$ used the service through governmental Weibo sites, 5.8\% used the service through governmental mobile apps, and 5.8\% used governmental services through Weixin (CNNIC, 2016).

Monitoring governmental policy-making process and other behavior

In the classical public policy research, public policy is defined as the "decisions (including both actions and non-actions) of a government" or "rules-in-use that structure behavioral situations involving public affairs, such as the sustained practices of street-level bureaucrats in delivering a public service" (Birkland, 2010, p. 9). Following previous research, we broadly define governmental policy process and behavior as the agenda setting, making, passing, implementation, adjustment, and annulment of a policy as well as any practices and behaviors of governmental employees during this process.

In recent years, Chinese netizens have been tremendously successful in using the Internet to monitor governmental employees' conduct and governmental policy processes and practices. The revelation of the misconduct of governmental officials on the Internet has caused the downfall of corrupt governmental officials in many cases. For instance, after a sex video involving the director of Beibei District of Chongqing was widely spread and disseminated online, netizens soon learned about the corruption surrounding governmental practices in Beibei. Within only a few days, the director, Mr. Lei Zhengfu, was removed from his position because of his corruption and misconduct. He later was sentenced to 13 years in prison. Monitoring the behavior of governmental officials during the policy process could cause the downfall of ministerial officials. After a female doctoral student was exposed online as having an extramarital affair with Yi Junqin, Director of the Central Compilation and Translation Bureau, in exchange for a job, he was soon stripped all his governmental positions.

In contemporary China, citizens also use the Internet to monitor the policy process. In many cases, citizens not only follow policies online but also discuss them, express their likes and dislikes, and even pressure the government to change certain policies. In recent years, it has been increasingly common for citizens to use the Internet to learn about governmental decisions relating to their daily lives and wellbeing, such as housing price regulations, environmental protection, and the rules that restrict driving. In other cases, citizens discuss the pros and cons of certain policies and eventually push for changes. For example, Chinese netizens participated in a heated discussion about the national policy, Detaining and Sending Back Urban Homeless and Beggars, after a recent college graduate, Mr. Sun Zhigang, was detained and beaten to death by a Guangzhou governmental agency because he has neither a permanent nor temporary residential card. Many netizens argued that this policy not only contravened the Chinese constitution but was also inhumane. The pressure by the online discussions eventually caused the State Council to announce the annulment of the policy three months after the Sun Zhigang murder.

Ever since China introduced public hearings as a new participatory instrument in the late 1990s, the Chinese public has started to pay more attention to the policy-making process; the 
Internet provides a convenient tool for this purpose (Fishkin, 2010; He and Warren, 2011; Peng et al., 2004). For example, in December 2007, on the Shanghai City Planning website, it was announced that a new magnetic levitation railway would be built from the Shanghai Hongqiao Airport to the South Train Station. Many residents of Shanghai, especially those who lived near the proposed magnetic levitation line, soon started posting threads on major online bulletin boards. In their posts, many people listed multiple reasons why a "maglev" should not be built. The main reason was that magnetic radiation could would be detrimental to their health because part of the maglev would cross residential neighborhoods. The citizens used various blogs and online bulletins not only to obtain the most updated news on governmental decision-making but also to voice their thoughts and opinions about the project. This case is an example of how citizens in China use the Internet to learn about a certain local policy as well as participate in and eventually influence the policy-making process. Chinese citizens can now use the Internet to monitor the government's management of public affairs and to quickly obtain and disseminate information about important governmental policy decisions that could influence their livelihood, health, and general wellbeing. In certain situations, they can even successfully influence the governments' management of public affairs.

\section{Collective actions and social protests}

Because the Chinese political system lacks effective institutionalized channels for interest articulation and political participation, many private citizens resort to social protests to voice their grievances. The number of social protests grew by nearly 12 times its original size from about 10,000 in 1993 to more than 130,000 in 2008 and then to 250,000 in 2012 (Ru et al., 2009; Zhang, 2015). Moreover, both the Internet and social media have developed rapidly and have become widely used by ordinary citizens, which enables them to connect with one another and to spread information more quickly than previously. Hence, the Internet is often used as a tool to organize collective actions and social protests. The Internet brings new blood into the dynamics of protest and helps to "disseminate information, formulate goals and strategies, identify opponents, and organize protest events” (Yang, 2003, p. 472), all of which occur rapidly at low cost but do not increase personal risk.

In contemporary China, the Internet can assist in collective actions in two ways. First, netizens can use the Internet to organize online protests. For instance, in 2009, local police arrested a 22-year-old female hotel employee, Deng Yujiao, after she stabbed three governmental officials in response their heinous request for sexual services and their attempts to rape her. Chinese netizens initiated a large online protest against the local police's charge of homicide. Some wrote poems and songs to praise the courageous and honorable deeds of Deng Yujiao. In another case, a 20-year girl, Guo Meimei, posted pictures on Weibo showing off her luxury cars and handbags and falsely claimed that she was a general manager of the Chinese Red Cross. The post was soon met with a large online protest by hundreds of thousands of netizens against the Chinese Red Cross, questioning its credibility. The online movement hampered private donations to the Chinese Red Cross, which decreased by about $87 \%$ in the following three months. In the face of this pressure from netizens, the Chinese Red Cross was forced to investigate this incident and to clarify the matter. These two examples illustrate that Chinese citizens mobilize online protests against certain social issues.

Second, netizens can use the Internet to mobilize and organize offline collective actions. In the protests against the construction of the Xiamen PX plant and the Shanghai magnetic levitation railway, the Internet and smart phones were critical tools for the involved residents to 
use in organizing offline protests. In the case of the Xiamen PX plant, not only did the residents use the Internet to mobilize thousands of people to participate in peaceful protests, they also used it to communicate with one another to finalize slogans and signs as well as the time and location of the protests. On 1 June 2007, mainly through organization via the Internet, at least 5,000 residents gathered at the public square in front of the city hall to protest against the PX plant project. The PX project was eventually aborted because of the massive opposition and pressure from citizens.

In another case, after a wealthy young man, Mr. Hu, who was driving a luxurious convertible, hit and killed a pedestrian in 2009, the police tried to cover it up, claiming in a press conference that he had not exceeded the speed limit. However, on the Internet, witnesses revealed that Hu's vehicle was speeding from 120-150 km/h when he hit the pedestrian, which was well above the legal speed limit. Furthermore, after the accident, Hu's attitude appeared to be extremely arrogant, and he asserted that he could get away with being deemed culpable by bribing the police. After the truth was revealed online, many netizens were furious and decided to organize a large protest against this travesty of justice. Almost 10,000 netizens gathered at the scene of the accident to grieve the death of the pedestrian. In all three cases, the Internet played a significant role in disseminating information about a social issue, mobilizing collective action, and organizing the time and location of protests.

Although the second type of collective action occurs offline, it promotes mobilization and organization online. We consider this type of collective action an important function of the Internet in political participation. In their recent research, Gibson and Cantijoch (2013) found that active, collective, and networked participatory activities are more likely to take in a so-called "hybrid" or "integrated" format. In other words, individuals l "use whatever tools are available to undertake their chosen action" whether in online or offline activities (Gibson \& Cantijoch, 2013, p.714). This finding is consistent with our observation of political participation in contemporary China. We consider online mobilization and organization of offline collective actions a key component of online political participation.

\section{Determinants of Political Participation in China}

Because of the Internet's role in contacting governments, monitoring policy-making process, and organizing collective actions, it is interesting to observe those who are more likely than others to participate in politics online. The resource theory of political participation (Brady, Verba, \& Schlozman, 1995) suggests that "given equal motivation to participate in the population, political activity should stratify by resources," and resources, such as time, money, and civic skills that require communication and organizational capacities all matter in political participation (Best and Krueger, 2005, p.186). Furthermore, political activity can be categorized into three groups depending on the required resources: those that require time, those that require monetary donations, and those that require voting. According to Salisbury (1975, p. 326), "Within any given population participation varies primarily along a single quantitative dimension, from less costly or difficult to more; and second, the foremost variable that explains this result is social class. Well-educated, high-income citizens participate more than the poor, no matter what the context or institutional setting."

Diverse types of political participation require different resources. Resources such as Internet skills influence the likelihood of online political participation because citizens need the skills required to overcome the "technical hurdles associated with navigating the Internet" (Best \& Krueger, 2005, p. 187; Bucy, 2000). In addition, Internet connections and home Internet 
access may influence a citizen's likelihood of online political engagement (Leigh \& Atkinson, 2001). Research has shown that connection speed influences online political activity (Krueger, 2002) and that a broadband connection increases the likelihood of online activity (Grubesic \& Murray, 2002). The reason is that a fast Internet connection facilitates not only downloading webpages and gathering information but also using multimedia applications because of the transmission of smooth videos and clear sound. Moreover, compared to public or work computer terminals, the home Internet connection offers greater opportunities, more privacy, and increased flexibility for online participation (e.g., National Telecommunications \& Information Administration [NTIA], 2000).

According to the resource theory of political participation, the access to social media should be a resource for political participation and therefore promotes online political participation. Nevertheless, opinions about this theory are divided. Some have argued that the Internet and social media foster political participation and develop a vocal and lively civil society (Jennings \& Zeitner, 2003; Mack, 2004; Norris, 2005; Shah et al., 2005; Uslaner 2004). Both provide an unprecedented venue for people to share their political opinions, reveal political scandals, and even mobilize protests in the virtual online community. Others have contended that both the Internet and social media are limited in fostering civic and political participation (Kraut et al. 1998; Nie \& Erbring, 2000; Putnam, 2000) because of governmental Internet censorship as well as reduced face-to-face interactions in online communication (Putnam 2000). Furthermore, although online discussions can be easily carried out through the Internet and social media, the discussions are often too discursive and shallow to facilitate true political participation. Another limitation of the Internet and social media is that the access to and use of social media do not automatically promote political participation. Members of interest organizations might view social network sites as valuable means for political participation, whereas their counterparts might prefer to remain passive and avoid sharing political views with others despite the exposure to political content and requests for participation (Gustafsson, 2012). The positive effects of online news on political engagement were higher in people with higher levels of political interest (Xenos \& Moy, 2007), and politically engaged citizens benefited more from the Internet's potential than their counterparts did (Bimber, 2003). Civic skills are also critical in online political participation, which include interacting with public officials and agencies, understanding domestic political system and policies, and critical thinking with regard to public affairs. Without these civic skills, it is impossible to participate effectively in the democratic process (Soltan, 1999).

In addition to the various resources for political participation, political interest is arguably a critical determinant. Political interest is one of the most powerful predictors of political participation, second only to evidence of previous participation (Holleque, 2011; Lane, 1959). Previous findings showed that those with more interest in public affairs or those who were more politically engaged were more likely to engage in political and civic activities (Bimber, 2003; Xenos \& Moy, 2007). Moreover, because the degree of political interest was found to remain relatively static over a person's life-cycle (Holleque, 2011), it could be it a reliable indicator of political participation. For this reason, we explore the ways in which political interest moderates the relationships between various resources and online political participation.

Political efficacy is a significant factor in political participation. Political efficacy can be defined as the feeling of an individual citizen that he or she can play a part in bringing about political and social change (Campbell, Gurin, \& Miller, 1954, cited in Kenski \& Stroud, 2006). There are two dimensions of political efficacy: internal political efficacy involves an individual's 
beliefs about his or her own competency in understanding and effective participation in politics (Brady, Verba, \& Schlozman, 1995), whereas external political efficacy refers to the individual's beliefs about the ability of government authorities and institutions to bring about desirable social and political change (Niemi, Craig, \& Mattei, 1991, cited in Kenski \& Stroud, 2006). Both internal and external political efficacy have a positive influence on an individual's political participation. Moreover, political participation could also exert an effect on perceived political efficacy (Finkel, 1985). Access to the Internet could enhance external political efficacy not only because citizens could interact with public officials but also because the Internet provides individuals with easy access to information about political candidates and public affairs. Moreover, the Internet could also increase an individual's internal political efficacy because of the anonymity afforded by the Internet. For these reasons, we control for the effect of political efficacy in our analysis of the determinants of online political participation.

\section{Research Hypotheses and Questions}

In this study, we examine three forms of online political participation: contacting government officials, monitoring public-policy-making process, and collective actions. Our main goal is to discover the determinants of this emerging type of political participation in China. We therefore focus on the role of the Internet in political participation and the resource theory of political participation. From the perspective of the resource theory of political participation, we propose the following research hypotheses:

H1: People with higher incomes are more active in political participation than their lower-income counterparts, including (a) contacting governmental officials, (b) monitoring public-policy-making process, and (c) participating in collective actions and social protests.

H2: Access to both computers and the Internet positively influence all three forms of political participation: (a) contacting governmental officials, (b) monitoring public-policymaking process, and (c) participating in collective actions and social protests.

H3: Internet-use skills positively influence all three forms of political participation: (a) contacting governmental officials, (b) monitoring public-policy-making process, and (c) participating in collective actions and social protests.

H4: People with higher levels of civic skills are more likely to engage in all three forms of political participation: (a) contacting governmental officials, (b) monitoring public-policymaking process, and (c) participating in collective actions and social protests.

In addition, we posit that political interest modifies the relationships examined above. Therefore, the following associated hypotheses are stated:

H5: Political interest moderates the relationships between (1) family income and contacting government and governmental officials online; (2) family income and monitoring the policy-making process online; and (3) family income and protesting online.

H6: Political interest moderates the relationships between (1) computer and Internet access and contacting government and governmental officials online; (2) computer and Internet 
access and monitoring the policy-making process online; and (3) computer and Internet access and protesting online.

H7: Political interest moderates the relationships between (1) Internet-use skills and contacting government and governmental officials online; (2) Internet-use skills and monitoring the policy-making process online; and (3) Internet-use skills and protesting online.

H8: Political interest moderates the relationship between (1) civic skills and contacting government and governmental officials online; (2) civic skills and monitoring the policy-making process online; and (3) civic skills and protesting online.

\section{Method}

\section{Participants}

The survey was conducted in November 2013 by a Chinese survey company, which had a database of more than 400,000 users in more than 31 provinces and districts of China. Among these, 17,035 Internet users were invited, and 1,202 participants participated (response rate = 7.06\%). All returned online surveys were reviewed by contacting the interviewees to confirm their responses.

The sample was weighted by gender to make it representative of the population. In the original sample, $60.3 \%$ were male, whereas $55.6 \%$ of the Chinese population is male. The weighted sample included $55.6 \%$ males, the average age of which was 32.87 years $(S D=8.30)$.

\section{Measures}

Income. The participants were asked to report their monthly family income. Twelve options were provided, ranging from less than RMB $¥ 1,000$, to between RMB $¥ 1,001$ and $¥ 2,000$, and to more than RMB $¥ 30,000$. In the analysis, the 12 categories were collapsed into five categories, including the lower class (12.3\%; family monthly income below RMB¥3,000); lowermiddle class (23.4\%, RMB¥3,000-¥6,000); middle class (24.4\%, RMB¥6,000-¥10,000), middleupper class (26.9\%; RMB¥10,000-¥20,000); and upper class (13.0\%; RMB¥20,000 and higher).

Computer and Internet access. To measure the participants' access to computers and the Internet, we asked the participants to indicate where they went online, including home, workplace, Internet cafes, friends' homes, anywhere with mobile-device Internet access, public places such as libraries, and other. In addition, they were asked to indicate the equipment they used to go online, including desk computer, laptop, tablet, smartphone, and other. To answer each question, the participants were instructed to select all the options that applied to them. The values derived from the two questions were added for each participant as an index of the degree of access to computers and the Internet (Cronbach's $\alpha=.72$ ).

Internet-use skills. We asked the participants to indicate they perceived their Internet-use skills on a 5-point Likert-type scale (1 = have no confidence in myself to $5=$ excellent).

Civic skills. We measured the participants' civic skills by adapting Brady, Verba, and Schlozman's (1995) measures of civic skills. In their study, they used the level of participation in student government in high school as well as the level of engagement in an organization such as writing a letter, going to a meeting where decisions are made, planning, or chairing a meeting, or giving a presentation or speech. We asked the participants to indicate on a 7-point scale $(1=$ 
never to 7 = very often) how frequently they participated in activities organized by communities, in volunteering, and in environmental advocacy activities.

Political participation (dependent variable). We adapted questions used in previous studies to measure Americans’ online political participation (e.g., Best \& Krueger, 2005, 2006, 2008; Krueger, 2002). We measured the participants' three forms of online participation by asking them to indicate how frequently they participated in the following activities on a 7-point scale $(1=$ never to 7 = very often): "give suggestions or express opinions to the government or its staff on the government's website (e.g., on the government's Weibo account)," "monitor the establishment, enforcement, adjustment, or annulment of a policy, or other governmental behavior on the Internet," and "organize or participate in protests online, hoping that it might influence governmental decisions.”

Political interest (moderating variable). The participants rated their political interests on a 3-item, 7-point Likert scale (1= strongly disagree to 7 = strongly agree) (Cronbach's $\alpha=.89)$ : "I am interested in political or public affairs," "I search for information on public affairs or politics through various channels," and "It is worth spending time thinking about politics or public affairs." The items were summed and averaged for each participant, $M=4.88, S D=1.16$.

Political efficacy (control variable). To measure political self-efficacy, the participants rated the following two items on a 7-point Likert scale (1= strongly disagree to $7=$ strongly agree) (Cronbach's $\alpha=.82$ ): "I think I am more than able to understand political issues," and "I am able to express my opinions on national and local issues." The mean was $4.83(S D=1.19)$. External political efficacy was measured by the following items on the same scale (Cronbach's $\alpha$ =.88): "The governmental decision-making system effectively respond to the public's reactions," and "the government and its officials actively and effectively respond to the public's reactions." The mean was $4.48(S D=1.29)$.

\section{Results}

Regarding $\mathrm{H} 1$, the results showed that household income was a significant predictor of contacting governmental officials online to express opinions after controlling for demographics, media use, and perceived internal and external political efficacy: $\beta=.15(S E=.04), t=4.10, p<$ .001. Income was also a significant predictor of online monitoring of policy-making process: $\beta=$ $.07(S E=.04), t=2.11, p<.05$. Income significantly predicted engagement in online protests to influence governmental policy-making: $\beta=.11(S E=.04), t=2.89, p<.01$. Therefore, H1a through c were supported (see Table 1).

Regarding H2, the results showed that controlling for demographics (including family income), media use, and perceived internal and external political efficacy, access to computers and the Internet was not a significant predictor of either online expression of opinions to governments, organizations, or participation in online protests: $\beta=.00(S E=.05), t=-0.70, p>$ .05 and $\beta=.05(S E=.06), t=0.80, p>.05$, respectively. However, controlling for demographics significantly predicted monitoring the policy-making process online: $\beta=.16(S E=.05), t=3.22$, $p<.001$. Therefore, H2b was supported, but H2a and H2c were not supported (see Table 2).

Regarding H3, the results showed that controlling for demographics (including family income), media use, and political efficacy beliefs, Internet-use skills did not predict contacting governmental officials online: $\beta=.10(\mathrm{SE}=.06), t=1.60, p>.05$. However, it was a significant predictor of other two forms of online political participation: monitoring the policy-making process online: $\beta=.20$ (SE =.06), $t=3.41, p<.001$, and online collective action: $\beta=.15$ (SE = 
.06), $t=2.28, p<.05$. Therefore, H3a was not supported, but H3b and H3c were supported (see Table 3).

Regarding $\mathrm{H} 4$, the results showed that after controlling for demographics (including family income), media use, political efficacy beliefs, and civic skills had a strong, positive relationship with the first form of online political participation: $\beta=.54(S E=.04), t=15.10, p<$ .001 . The same results were found for the online monitoring of the policy-making process: $\beta=$ $.32(S E=.04), t=8.80, p<.001$, and for organizing and participating in online protests: $\beta=.50$ $(S E=.04), t=14.64, p<.001$. Therefore, H4a through c were supported (see Table 4).

Regarding $\mathrm{H} 5 \mathrm{a}$, the results showed that the interaction of contacting governmental officials online to express opinions was significant: $\beta=.10(S E=.03), t=3.50, p<.001$. The positive sign indicates that as political interest increased, the correlation between family income and contacting government and governmental officials increased. In testing H5b, the interaction between political interest and family income had a significant effect on monitoring the policymaking process online: $\beta=.05$ ( $S E=.03$ ), $t=1.98, p<.05$. This result indicated that the effect of family income on online monitoring of policy-making process was stronger among individuals with a high level of political interest. In testing H5c, the results showed that the interaction between political interest and family income had a significant effect on participation in protesting online: $\beta=.11$ (SE =.03), $t=3.76, p<.01$. Among individuals with high levels of political interest, the relationship between family income and online protesting was stronger, and those with higher income were more likely to participate in online protests. Therefore, the results supported H5a, H5b, and H5c.

In testing H6, the results showed that political interest did not moderate the relationship between computer and Internet access and contacting governmental officials online: $\beta=.08$ (SE $=.04), t=1.80, p>.05$. Neither did it moderate the relationship between computer and Internet access and monitoring the policy-making process online: $\beta=.03(S E=.04), t=0.67, p>.05$. The results for online protesting were as follows: $\beta=.06(S E=.04), t=1.33, p>.05$. Therefore, H6a, H6b, and H6c were not supported (see Table 2).

In testing $\mathrm{H7}$, the results showed that political interests moderated the relationship between Internet-use skills and contacting governmental officials online: $\beta=.14(S E=.05), t=$ $3.05, p<.05$. This result indicates that among people who were highly interested in politics, the correlation under examination was stronger than those with low levels of political interest. Political interest also significantly moderated the relationship between Internet-use skills and online collective action: $\beta=.13(S E=.05), t=2.63, p<.01$. However, the moderation of political interest was not significant regarding monitoring the policy-making process online: $\beta=$ $.05(S E=.04), t=1.15, p>.05$. Consequently, H7a and H7c were supported, but H7b was not supported (see Table 3).

In testing $\mathrm{H} 8$, the results showed that political interest had no significant moderating effect on contacting government online: $\beta=-.01(S E=.02), t=-.36, p>.05$. The same results were found for the monitoring of the policy-making process online: $\beta=-.01$ (SE =.02), $t=-.62$, $p>.05$. Similarly, the results for online protesting and collective action were as follows: $\beta=.01$ $(S E=.02), t=0.52, p>.05$. Therefore, H8a, H8b, and H8c were not supported (see Table 4).

\section{Discussion}

The current study drew on the resource theory of political participation to examine the influence of various resources on the online political participation of Chinese citizens. Previous research showed that through the Internet, Chinese citizens increasingly obtained political information, 
expressed their political opinions, interacted with the government, participated in policy-making process, and monitored the enforcement of public policies (Chen, 2011; Chen \& Du, 2005; Lu \& Pan, 2015; Zhao \& Chen, 2013). Despite these fruitful research studies, the research on the predictors of online political participation in China is limited. The current study bridged this research gap by drawing on the resource model of political participation. The findings showed that among the many predictors of online political participation, income significantly predicted all three forms of online political participation. People with higher financial status were more likely to contact government and its staff online, monitor public policies online, and organize and participate in online collective actions such as protests. These findings therefore support the resource theory of political participation by showing that both education and income were the most important factors in the propensity to voting (Tolbert \& McNeal, 2003). The significance of income in predicting Chinese online political participation is consistent with many previous studies. For instance, Krueger (2002) argued that individuals with higher socioeconomic profiles access the Internet at the highest rates and are the most likely to utilize the new medium to participate in politics (cited in Anderson et al., 1995; Bimber, 2003). Other studies (Norris, 1999; Solop, 2000) examined the profile of individuals who participated in politics via the Internet and confirmed that those participating in politics online had higher socioeconomic backgrounds than the population at large.

In addition to income, an important predictor of online political participation was civic skills. The present study found that civic skills was a significant determinant of all three forms of online political participation: contacting government officials online, monitoring public policies online, and participation in online protests. As defined by Brady, Verba, and Schlozman (1995), civic skills are the communications and organizational skills that facilitate effective participation in political affairs. Our findings in this regard were consistent with the previous research. For instance, Brady, Verba and Schlozman (1995) found that individuals who possessed more resources such as civic skills were able to overcome the high costs of political engagement and therefore were more likely to participate in politics. It was also reported that civic education in school could compensate for missing parental political socialization and boost the level of political engagement in youth (Neundorf, Niemi, \& Smets, 2016).

Our study found that access to computers and the Internet increased the possibilities of online political participation. Past research showed that access to the Internet significantly predicted voting in American presidential elections. Moreover, it was proposed that the Internet increases the likelihood of exposure to election news and candidates' information, which consequently stimulates political participation (Tolbert \& McNeal, 2003). Our study found that the access to computers and the Internet were critical determinants of Chinese citizens' online monitoring of public policies, but it was not predictive of contacting governmental officials online or participating in online protests. It is plausible that contacting governmental officials online and participating in online collective actions are riskier than monitoring public policies online because of strict Internet censorship, political repression, and the heavy-handed tactics used in response to those who oppose the state.

This study found that not only access to computers and the Internet but also Internet-use skills were a significant predictor of online collective action and monitoring the policy-making process online. People with greater skills in using the Internet were more likely to participate in online collective action and to monitor policy-making process online. These findings complement the resource theory of political participation and suggest that there are additional contributing factors of online political participation. Individuals with easier Internet access and 
higher proficiency in Internet-use are more likely to navigate the Internet and use it for online political participation (Best \& Krueger, 2005; Bucy, 2000).

A concept related to the benefits of Internet access and Internet-use skills is technological affordance, which is defined as the possibilities and opportunities that emerge from using a focal technology (Bloomfield, Latham, \& Vurdubakis, 2010). Bennett and Segerberg (2013) maintained that the Internet's positive impact on political participation arises from its technological affordance. Similarly, Earl and Kimport (2011) argued that with the aid of Internet technology, movement entrepreneurs could organize big-scale social protests or movements at little cost, and online protests have greatly influenced the direction of social transformation and political development in China (Yu, 2013). Because of the strict governmental control over information in the nation, bottom-up cultural change rather than top-down institutionalized change is pivotal in the pursuit of democratic principles, and social media play an essential role in this process.

Our findings also suggested that political interest was a pivotal factor in political participation and positively moderated the association of family income with each of the three forms of online political participation. That is, for people with high levels of political interest, the association between income and online political participation was stronger, and income had more profound political implications among those who were more interested in politics than among those who were less interested in politics.

Our results might be interpreted as having negative implications for China's political future, because they indicate that individuals from higher socioeconomic backgrounds are more likely to participate in politics online. As the income disparity between the rich and the poor widens, the political contest between the rich and the poor may intensify, especially if the rich garner more political resources through their more active participation. However, another interpretation of the results shows a promising picture. In China, online political participation is more commonly used by the younger generation, which has more Internet access and better Internet skills. Although the wealthy and educated class is more likely to participate online, the Internet and social media, as a new tool of political participation, include and encourage the entry of new groups of people into the political process. This new group, namely, the younger generation and the generation that uses the new technology, will likely play an active role in the political and economic processes in the future. Although the new information technology may not necessarily eliminate the gap in online political participation between groups with high and low socioeconomic resources, it definitely offers the potential to reduce it.

Importantly, our findings indicated that socioeconomic resources are not alone in predicting online political participation. With regard to political interest, socioeconomic resources can be a predictor of online political participation. Individuals with higher levels of interest in politics are much more likely to utilize this new tool to participate in politics. In recent years, as social media such as WeChat and Weibo have become increasingly popular in China, we saw an increasing trend toward a higher number of disadvantaged citizens with grievances utilizing these social media tools to express their opinions or to solve their problems. This usage is precisely when political interests are at work. Therefore, promoting political interest among the poor may be another way to tackle the imbalance in political participation between the rich and the poor in contemporary China.

Our study has the following limitations. As the Internet and social media have enriched the dynamics of online political participation in recent years, scholars have found it increasingly difficult to separate offline and online political participation (Gibson \& Cantijoch, 2013; 
Weinberg \& Williams, 2006). Gibson and Cantijoch (2013) found that active, collective, and networked participatory activities were likely to take a hybrid format and that individuals would use whatever tools were available to undertake their action regardless of online or offline activities (Gibson \& Cantijoch, 2013). For example, it is common for individuals in China to use the Internet to mobilize a protest online, but the protest itself actually takes place offline, as some of our examples have shown. Therefore, it is possible that individuals who admitted having used the Internet to participate in a collective action may have used offline means to carry out the collective action. After Gibson and Cantijoch's seminal work on hybrid political participation, more attention has been paid to whether online and offline participation can be fully separated or not. Although our study examined the online component of political participation, it did not consider the hybrid version of political participation. Therefore, further research is needed that incorporates both formats of political participation.

We also note that it is common that individuals can use more than one format to carry out their chosen political action. For example, while monitoring governmental policy process, individuals can reach out to the government and contact its officials. If they do not receive satisfactory results, they can then proceed to mobilize a collective action. For this reason, future research could integrate the three forms and assess overall political participation online. Another drawback of the current study is that the three online political participation activities do not constitute an exhaustive list of participatory activities in China. Therefore, future studies should reflect all the unique features of political participation in China. We mainly relied on our survey questions to differentiate online and offline participation, and our future work on this topic will further examine and address this issue.

\section{Notes on contributors}

Ping $\mathbf{X u}$ is an associate professor of political science at the University of Rhode Island. Her research interests include public opinion and political behavior, political economy, globalization, immigration, and Chinese politics. Her research has been published in the American Journal of Political Science, Policy Studies Journal, The China Quarterly, Telematics and Informatics, American Politics Research, State Politics and Policy Quarterly, among others.

Yinjiao Ye is an associate professor in the Department of Communication Studies at the University of Rhode Island. Her research interests include social media, health communication, and media effects. Her research has appeared in several publications, including the Journal of Health Communication, Health Communication, Computer and Human Behavior, Mass Media and Society, International Journal of Environmental Research and Public Health, Telematics and Informatics.

Mingxin Zhang is a professor in the School of Journalism and Communication at Huazhong University of Science \& Technology. His research focuses on new media studies, political communication, and national strategic communication. His research has been published in journals such as Telematics and Informatics, Information Research, China Media Research, among others.

\section{References}


Anderson, R. H., Bikson, T. K., Law, S. A., \& Mitchell, B. M. (1995). Universal access to Email: Feasibility and societal implications. Santa Monica, CA: Rand.

Bennett, W. L., \& Segerberg, A. (2013) The logic of connective action: Digital media and the personalization of contentious politics. New York: Cambridge University Press.

Best, S. J., \& Krueger, B. S. (2005). Analyzing the representativeness of Internet political participation. Political Behavior, 27, 183-216. doi:10.1007/s11109-005-3242-y

Best, S. J., \& Krueger, B. S. (2006). Online interactions and social capital: Distinguishing between new and existing ties. Social Science Computer Review, 24(4), 395-410. doi:10.1177/0894439306286855

Best, S. J., \& Krueger, B. S. (2008). Political conflict and public perceptions of government surveillance on the internet: An experiment of online search terms. Journal of Information Technology \& Politics, 5(2),191-212. doi:10.1080/19331680802294479

Birkland, T. A. (2010). An introduction to the policy process (3rd ed.). Armonk, NY: M.E. Sharpe.

Bimber, B. (2003). Information and American democracy technology in the evolution of political power. Cambridge, UK: Cambridge University Press.

Bloomfield, B. P., Latham, Y., \& Vurdubakis, T. (2010). Bodies, technologies and action possibilities: When is an affordance? Sociology, 44(3), 415-433.

Brady, H. E., Verba, S. \& Schlozman, K. L. (1995). Beyond SES: A resource model of political participation. American Political Science Review, 89, 271-294. doi: 10.2307/2082425

Bucy, E. P. (2000). Social access to the Internet. International Journal of Press/politics, 5(1), 50-61.

Campbell, A., Gurin G., \& Miller, W. E. (1954). The voter decides. Evanston, IL: Row, Peterson and Company.

Chen, J. (2011). Popular political support in urban China (J. An, Trans.). Stanford, NJ: Stanford University Press.

Chen, S., \& Du, J. (2005). The public forums on the Internet: The rise of political participation and consultative democracy. Journal of Zhejiang University (Humanities and Social Sciences), 35(3), 5-12.

Chen, X., \& Xu, P. (2011). From resistance to advocacy: Political representation for disabled people in China. The China Quarterly, 207, 649-667.

Chen, Y. (2011). The restlessness of online populism: From virtual gathering to social movements. Scholarship Monthly, 43, 24-29.

China Internet Network Information Center. (2016, August 3). The $38^{\text {th }}$ report of China's Internet development. Retrieved from http://www.cnnic.net.cn/hlwfzyj/hlwxzbg/hlwtjbg/201608/P020160803367337470363.pd $\mathrm{f}$

China Research and Data Center at Renmin University of China. (2009). A comprehensive research report of Chinese general social survey (2003-2008). Beijing, China: China Society Press.

Conover, P. J. (1995). Citizen identities and conceptions of the self. The Journal of Political Philosophy, 3, 133-165. doi: 10.1111/j.1467-9760.1995.tb00032.x

Earl, J., \& Kimport, K. (2011). Digitally enabled social change: Activism in the Internet age. Cambridge, MA: MIT Press.

Finkel, S. E. (1985). Reciprocal effects of participation and political efficacy: A panel analysis. American Journal of Political Science, 29(4), 891-913. 
Fishkin, J. S., He, B., Luskin, R. C., \& Siu, A. (2010). Deliberative democracy in an unlikely place: Deliberative polling in China. British Journal of Political Science, 40(2), 435-448.

Gibson, R., \& Cantijoch, M. (2013). Conceptualizing and measuring participation in the age of the Internet: Is online political engagement really different to offline? The Journal of Politics, 75(3), 701-716.

Grubesic, T., \& Murray, A. (2002). Constructing the divide: Spatial disparities in broadband access. Papers in Regional Science, 81, 197-221.

Gustafsson, B., Li, S., \& Sicular, T. (2008). Inequality and public policy in China. New York, NY: Cambridge University Press.

Gustafsson, N. (2012). The subtle nature of Facebook politics: Swedish social network site users and political participation. New Media \& Society, 14, 1111-1127. doi: $10.1177 / 1461444812439551$

Hartford, K. (2005). Dear Mayor: Online communications with local governments in Hangzhou and Nanjing. China Information, 19, 217-260.

He, B., \& Warren, M. E. (2011). Authoritarian deliberation: The deliberative turn in Chinese political development. Perspectives on Politics, 9(2), 269-289.

Holleque, M. (2011). Rethinking the stability of political interest. Retrieved from http://users.polisci.wisc.edu/behavior/Papers/holleque_stability_04_08_11.pdf

Hu, R. (2008). Social capital and city residents' political participation. Politics Research, 5, 142159.

Irwin, L. G. (2003). The policy analyst's handbook: Rational problem solving in a political world. New York, NY: Routledge.

Jennings, M. K. (1997). Political participation in the Chinese countryside. The American Political Science Review, 91, 361-372.

Jennings, M. K. (1998). Gender and political participation in the Chinese countryside. The Journal of Politics, 60(4), 954-973.

Jennings, M. K., \& Zeitner, V. (2003) Internet use and civic engagement: A longitudinal analysis. Public Opinion Quarterly, 67, 331-334.

Jiang, M. \& Xu, H. (2009): Exploring online structures on Chinese government portals: Citizen political participation and government legitimation. Social Science Computer Review, 27, 174-195. doi: 10.1177/0894439308327313

Johnson, D. (2010). Spectacle and sacrifice: The ritual foundations of village life in north China. Cambridge, MA: Harvard University, Asia Center.

Kenski, K., \& Stroud, N. J. (2006). Connections between Internet use and political efficacy, knowledge, and participation. Journal of Broadcasting \& Electronic Media, 50, 173-192.

Kraut, R., Patterson, M., Lundmark, V., Kiesler, S., Muko-Padhyay, T., \& Scherlis, W. (1998). Internet paradox: A social technology that reduces social involvement and psychological well-being? American Psychologist, 53(9), 1017-1031.

Krueger, B. S. (2002). Assessing the potential of Internet political participation in the United States: A resource approach. American Politics Research, 30, 476-498.

Lane, R. E. (1959). Political life: Why people get involved in politics. New York: Free Press, 1959.

Leigh, A., \& Atkinson, R. (2001). Clear thinking on the digital divide. Washington, DC: Progressive Policy Institute.

Longest, B. B. (1998). Health policy making in the U.S. (2nd ed.) Chicago, IL: Health Administration Press. 
Li, L. (2008). Political trust and petitioning in the Chinese countryside. Comparative Politics, 40, 209-226.

Lu, S., \& Pan, Q. (2015). The study of contemporary Chinese youth online political participation. Chinese Youth Social Sciences, 1, 61-66.

Mack, T. C. (2004). Internet communities: The future of politics? Futures Research Quarterly, 20, 61-77.

National Telecommunications \& Information Administration. (2000). Falling through the net: Toward digital inclusion. Washington, DC: U.S. Department of Commerce.

Neundorf, A., Niemi, R. G., \& Smets, K. (2016). The compensation effect of civic education on political engagement: How civics classes make up for missing parental socialization. Political Behavior, 38, 921-949.

Nie, N. H., \& Erbring, L. (2000). Internet and society: A preliminary report. Retrieved from http://www.nomads.usp.br/documentos/textos/cultura_digital/tics_arq_urb/internet_societ y\%20report.pdf

Niemi, R. G., Craig, S. C., \& Mattei, F. (1991). Measuring internal political efficacy in the 1988 National Election Study. American Political Science Review, 85, 1407-1413.

Norris, P. (1999). Who surfs? New technology, old voters and virtual democracy in the 1996 and 1998 US elections. Retrieved from https://sites.hks.harvard.edu/fs/pnorris/Acrobat/WhoSurfs\%20Revised\%202001.pdf

Norris, P. (2005). The impact of the Internet on political activism: Evidence from Europe. International Journal of Electronic Government Research, 1, 20-39.

Ostrom, E. (1980). Is it B or not-B? That is the question. Social Science Quarterly, 61, 198-202.

Peng, Z., Lan, X., \& Ke, K. (2004). The public hearing system in China. Beijing, China: Tsinghua University Press.

Putnam, R. D. (2000). Bowling alone: America's declining social capital. In L. Crothers \& C. Lockhart (Eds.), Culture and politics: A reader (pp. 223-234). New York: St. Martin’s Press.

Ru, X., Lu, X., Li, P., Chen, G., Li, W., \& Xu, X. (2009). The blue book of China's society: Analysis and forecast. Beijing, China: China's Academy of Social Sciences Press.

Sabatier, P. A., \& Weible, C. M. (Eds.). (2014). Theories of the policy process. Westview Press.

Schneider, A. L., \& Ingram, H. (1997). Policy design for democracy. Lawrence: University Press of Kansas.

Salisbury, R. H. (1975). Research on political participation. American Journal of Political Science, 19, 323-341. doi: 10.2307/2110440.

Shah, D. V., Cho, J., Eveland, W. P. Jr., \& Kwak, N. (2005). Information and expression in a digital age: Modeling Internet effects on civic participation. Communication Research, 32, 531-565.

Solop, F. I. (2000). Digital democracy comes of age in Arizona: Participation and politics in the first binding Internet election. Presented at Annual Meeting of the American Political Science Association, Washington, DC.

Soltan, K. E. (1999). Civic competence, attractiveness, and maturity. In S. L. Elkin \& K. E. Soltan (Eds.), Citizen, competence, and democratic institutions (pp. 17-37). University Park, PA: The Pennsylvania State University Press.

Tao, D., \& Chen, M. (1999). Political participation in modern China. Hangzhou, China: Zhejiang Renmin Press. 
Tolbert, C. J., \& McNeal, R. S. (2003). Unraveling the effects of the Internet on political participation? Political Research Quarterly, 56, 175-185.

Uslaner, E. M. (2004). Corruption, inequality, and trust. In G. T. Svendsen \& G. L. H. Svendsen (Eds.). The handbook on social capital. London: Edward Elgar. Retrieved from http://gvptsites.umd.edu/uslaner/uslanersocialcapitalhandbookelgar.pdf

Wang, L., \& Fang, R. (2010). Participate or not participate? An analysis of social psychology of Chinese citizens' political participation based on a survey. Politics Research, 2, 95-108.

Wedeman, A. (2005). Anticorruption campaigns and the intensification of corruption in China. Journal of Contemporary China, 14, 93-107.

Weible, C. (2014). Introducing the scope and focus of policy process research and theory. In P. A. Sabatier \& C. M. Weible (Eds.), Theories of the policy process (3rd ed.), pp. 3-21 Boulder, CO: Westview Press.

Weinberg, B. D., \& Williams, C. B. (2006). The 2004 US Presidential campaign: Impact of hybrid offline and online "meetup" communities. Direct, Data and Digital Marketing Practice, 8(1), 46-57.

Xenos, M. A., \& Moy, P. (2007). Direct and differential effects of the Internet on political and civic engagement. Journal of Communication, 57, 704-718.

Yang, G. (2003). The Internet and civil society in China: A preliminary assessment. Journal of Contemporary China, 12, 453-475.

Yang, G. (2007). How do Chinese civic associations respond to the Internet: Findings from a survey. The China Quarterly, 189, 122-143.

Yu, J. (2013). The dilemma and solution to public participation in the era of self-media: The cases of important collective events. Shanghai University Research Journal (Social Sciences), 4, 1-8.

Zhang, M. (2015). The rise of participatory politics in China: An empirical study of Chinese Internet users' political psychology and behavior. Wuhan, China: Huazhong University of Science and Technology Press.

Zhao, D., \& Chen, G. (2013). The status-quo of college students' political participation on Weibo. Online Governmental Affairs, 3, 39-46. 
Tables

Table 1

Regression Results of Using Income as A Predictor of Online Political Participation

\begin{tabular}{|c|c|c|c|c|c|c|}
\hline \multirow{3}{*}{ Independent variable } & \multicolumn{6}{|c|}{ Dependent variable } \\
\hline & \multicolumn{2}{|c|}{$\begin{array}{l}\text { Contacting } \\
\text { government online }\end{array}$} & \multicolumn{2}{|c|}{$\begin{array}{l}\text { Online monitoring } \\
\text { of public policies }\end{array}$} & \multicolumn{2}{|c|}{$\begin{array}{l}\text { Participation in } \\
\text { online protests }\end{array}$} \\
\hline & $\beta(S E)$ & $t$ & $\beta(S E)$ & $t$ & $\beta(S E)$ & $t$ \\
\hline \multicolumn{7}{|l|}{ Demographics } \\
\hline Gender & $.08(.08)$ & .90 & $.01(.08)$ & .18 & $.06(.09)$ & .75 \\
\hline Age & $-.26(.05)^{* * *}$ & -4.85 & $-.25(.05)^{* * *}$ & -4.98 & $-.46(.06)^{* * *}$ & -8.32 \\
\hline Occupation & & & & & & \\
\hline (have a job=1) & $.32(.11)$ & 2.83 & $.04(.11)$ & .33 & $.15(.12)$ & 1.27 \\
\hline Education & $-.01(.06)$ & -.24 & $.02(.06)$ & .34 & $-.07(.06)$ & -1.09 \\
\hline \begin{tabular}{ll} 
Party & \multicolumn{2}{r}{ affiliation } \\
& (Communist party \\
& $=1)$ \\
$\Delta R^{2} \%$ &
\end{tabular} & $\begin{array}{l}.05(.10) \\
5.1^{* * *} \\
\end{array}$ & .53 & $\begin{array}{l}.21(.09)^{*} \\
5.3^{* * *}\end{array}$ & 2.27 & $\begin{array}{l}.18(.10) \\
6.0^{* * *}\end{array}$ & 1.73 \\
\hline \multicolumn{7}{|l|}{ Media use } \\
\hline Reading newspapers & $.12(.05)^{* *}$ & 2.71 & $.07(.04)$ & 1.67 & $.12(.05)^{* *}$ & 2.58 \\
\hline Watching TV & $.03(.05)$ & .55 & $.04(.05)$ & .80 & $.02(.05)$ & .42 \\
\hline Surfing on the Internet & $-.15(.05)^{* *}$ & -3.02 & $-.02(.05)$ & -.31 & $-.15(.05)^{* *}$ & -2.81 \\
\hline$\Delta R^{2} \%$ & $7.3^{* * *}$ & & $6.0^{* * *}$ & & $6.3^{* * *}$ & \\
\hline Internal political efficacy & $.29(.05)^{* * *}$ & 5.46 & $.19(.05)^{* *}$ & 3.69 & $.28(.06)^{* * *}$ & 4.92 \\
\hline External political efficacy & $.20(.04)^{* * *}$ & 4.83 & $.07(.04)$ & 1.70 & $.06(.04)$ & 1.49 \\
\hline$\Delta R^{2} \%$ & $18.8^{* * *}$ & & $16.8^{* * *}$ & & $14.5^{* * *}$ & \\
\hline \multicolumn{7}{|l|}{ Resources } \\
\hline Household income & $.15(.04)^{* * *}$ & 4.10 & $.07(.04)^{*}$ & 2.11 & $.11(.04)^{* *}$ & 2.89 \\
\hline Political interest & $.28(.06)^{* * *}$ & 4.98 & $.50(.05)^{* * *}$ & 9.34 & $.37(.06)^{* * *}$ & 6.24 \\
\hline \multicolumn{7}{|l|}{ Political interest } \\
\hline$\times$ household income & $.10(.03)^{* * *}$ & 3.50 & $.05(.03)^{*}$ & 1.98 & $.11(.03)^{* * *}$ & 3.76 \\
\hline$\triangle R^{2} \%$ & $3.1^{* * *}$ & & $5.4^{* * *}$ & & $3.7^{* * *}$ & \\
\hline Adj. $R^{2} \%$ & $33.6^{* * * *}$ & & $32.8^{* * *}$ & & $29.7^{* * * *}$ & \\
\hline
\end{tabular}


Table 2

Regression Results of Using Computer and Internet Access to Predict Online Political Participation

\begin{tabular}{|c|c|c|c|c|c|c|}
\hline \multirow{3}{*}{ Independent Variable } & \multicolumn{6}{|c|}{ Dependent Variable } \\
\hline & \multicolumn{2}{|c|}{$\begin{array}{l}\text { Contacting } \\
\text { government online }\end{array}$} & \multicolumn{2}{|c|}{$\begin{array}{l}\text { Online monitoring } \\
\text { of public policies }\end{array}$} & \multicolumn{2}{|c|}{$\begin{array}{l}\text { Participation in } \\
\text { online protests }\end{array}$} \\
\hline & $\beta(S E)$ & $t$ & $\beta(S E)$ & $t$ & $\beta(S E)$ & $t$ \\
\hline \multicolumn{7}{|l|}{ Demographics } \\
\hline Gender & $.06(.08)$ & .68 & $.00(.08)$ & .04 & $.04(.09)$ & .50 \\
\hline Age & $-.26(.05)^{* * *}$ & -4.98 & $-.24(.05)^{* * *}$ & -4.75 & $-.46(.06)^{* * *}$ & -8.32 \\
\hline \multicolumn{7}{|l|}{ Occupation } \\
\hline (have a job = 1) & $.31(.12)^{* *}$ & 2.67 & $-.02(.11)$ & -.14 & $.12(.12)$ & .98 \\
\hline Education & $-.03(.06)$ & -.56 & $-.01(.06)$ & -.25 & $-.10(.06)$ & -1.53 \\
\hline \multicolumn{7}{|l|}{ Party affiliation } \\
\hline (Communist Party = 1) & $.06(.10)$ & .63 & $.23(.09)^{*}$ & 2.55 & $.20(.10)$ & 1.90 \\
\hline Household income & $.15(.04)^{* * *}$ & 4.12 & $.06(.04)$ & 1.82 & $.12(.04)^{* *}$ & 2.86 \\
\hline$\triangle \mathrm{R}^{2} \%$ & $10.1^{* * *}$ & & $8.6^{* * *}$ & & 9.5 & \\
\hline \multicolumn{7}{|l|}{ Media use } \\
\hline Reading newspapers & $.12(.05)^{* *}$ & 2.69 & $.06(.04)$ & 1.30 & $.12(.05)^{*}$ & 2.45 \\
\hline Watching TV & $.03(.05)$ & .54 & $.04(.05)$ & .80 & $.02(.05)$ & .46 \\
\hline Surfing on the Internet & $-.14(.05)^{* *}$ & -2.71 & $-.04(.05)$ & -.82 & $-.15(.05)^{* *}$ & -2.69 \\
\hline$\triangle \mathrm{R}^{2} \%$ & $6.0^{* * *}$ & & $4.8^{* * *}$ & & 5.3 & \\
\hline Internal political efficacy & $.29(.05)^{* * *}$ & 5.42 & $.18(.05)^{* * 7}$ & 3.61 & $.27(.06)^{* * *}$ & 4.86 \\
\hline External political efficacy & $.21(.04)^{* * *}$ & 5.13 & $.07(.04)$ & 1.81 & $.08(.04)$ & 1.78 \\
\hline$\triangle \mathrm{R}^{2} \%$ & $16.3^{* * *}$ & & $15.1^{* * *}$ & & 12.7 & \\
\hline \multicolumn{7}{|l|}{ Resources } \\
\hline Computer \& Internet access & $.00(.05)$ & -.07 & $.16(.05)^{* * *}$ & 3.22 & $.05(.06)$ & .80 \\
\hline Political interest & $.28(.06)^{* * *}$ & 4.87 & $.48(.05)^{* * *}$ & 9.06 & $.36(.06)^{* * *}$ & 6.03 \\
\hline \multicolumn{7}{|l|}{ Political interest } \\
\hline$\times$ Computer/Internet access & $.08(.04)$ & 1.80 & $.03(.04)$ & 0.67 & $.06(.04)$ & 1.33 \\
\hline$\triangle \mathrm{R}^{2} \%$ & $1.5^{* * *}$ & & $5.4^{* * *}$ & & $2.3^{* * *}$ & \\
\hline Adj.R ${ }^{2} \%$ & $33.0^{* * *}$ & & $33.1^{* * *}$ & & $29.0^{* * *}$ & \\
\hline
\end{tabular}


Table 3

Regression Results of Using Internet-Use Skills as A Predictor of Online Political Participation

\begin{tabular}{|c|c|c|c|c|c|c|}
\hline \multirow{3}{*}{ Independent variable } & \multicolumn{6}{|c|}{ Dependent variable } \\
\hline & \multicolumn{2}{|c|}{$\begin{array}{l}\text { Contacting } \\
\text { government online }\end{array}$} & \multicolumn{2}{|c|}{$\begin{array}{l}\text { Online monitoring } \\
\text { of public policies }\end{array}$} & \multicolumn{2}{|c|}{$\begin{array}{l}\text { Participation in } \\
\text { online protests }\end{array}$} \\
\hline & $\beta(S E)$ & $t$ & $\beta(S E)$ & $t$ & $\beta(S E)$ & $t$ \\
\hline \multicolumn{7}{|l|}{ Demographics } \\
\hline Gender & $.05(.08)$ & .57 & $-.02(.08)$ & -.25 & $.03(.09)$ & .33 \\
\hline Age & $-.26(.05)^{* * *}$ & -4.98 & $-.25(.05)^{* * *}$ & -4.97 & $-.46(.06)^{* * *}$ & -8.41 \\
\hline \multicolumn{7}{|l|}{ Occupation } \\
\hline (have a job =1 ) & $.29(.11)^{*}$ & 2.51 & $.01(.11)$ & .08 & $.11(.12)$ & .91 \\
\hline Education & $-.03(.06)$ & -.54 & $-.01(.06)$ & -.11 & $-.10(.06)$ & -1.50 \\
\hline \multicolumn{7}{|l|}{ Party affiliation } \\
\hline$($ Communist Party $=1)$ & $.05(.10)_{* * *}$ & .51 & $.20(.09)^{*}$ & 2.22 & $.18(.10)_{* *}$ & 1.72 \\
\hline Household income & $.14(.04)^{* * *}$ & 3.84 & $.06(.04)$ & 1.64 & $.10(.04)^{* *}$ & 2.57 \\
\hline$\triangle \mathrm{R}^{2} \%$ & $10.1^{* * *}$ & & $8.6^{* * *}$ & & $9.5^{* * *}$ & \\
\hline \multicolumn{7}{|l|}{ Media use } \\
\hline Reading newspapers & $.12(.05)^{* *}$ & 2.64 & $.06(.04)$ & 1.42 & $.12(.05)^{* *}$ & 2.43 \\
\hline Watching TV & $.03(.05)$ & .50 & $.04(.05)$ & .76 & $.02(.05)$ & .39 \\
\hline Surfing on the Internet & $-.16(.05)^{* *}$ & -3.06 & $-.04(.05)$ & -.75 & $-.16(.05)^{* *}$ & -2.96 \\
\hline$\triangle R^{2} \%$ & $6.0^{* * * *}$ & & $4.8^{* * *}$ & & $5.3^{* * *}$ & \\
\hline Internal political efficacy & $.28(.05)^{* * *}$ & 5.26 & $.17(.05)^{*}$ & 3.41 & $.26(.06)^{* *}$ & 4.67 \\
\hline External political efficacy & $.20(.04)^{* * *}$ & 5.00 & $.07(.04)$ & 1.75 & $.07(.04)$ & 1.66 \\
\hline$\triangle \mathrm{R}^{2} \%$ & $16.3^{* * *}$ & & $15.1^{* * *}$ & & $12.7^{* * *}$ & \\
\hline \multicolumn{7}{|l|}{ Resources } \\
\hline Internet-use skills & $.10(.06)_{* * *}$ & 1.60 & $.20(.06)_{* * * *}^{* * *}$ & 3.41 & $.15(.06)_{* * *}^{*}$ & 2.28 \\
\hline Political interest & $.27(.06)^{* * *}$ & 4.70 & $.49(.05)^{* * *}$ & 9.07 & $.35(.06)^{* * *}$ & 5.92 \\
\hline \multicolumn{7}{|l|}{ Political interest } \\
\hline$\times$ Internet-use skills & $.14(.05)^{* *}$ & 3.05 & $.05(.04)$ & 1.15 & $.13(.05)^{* *}$ & 2.63 \\
\hline$\triangle \mathrm{R}^{2} \%$ & $2.0^{* * * *}$ & & $5.5^{* * *}$ & & $2.9^{* * *}$ & \\
\hline Adj. $\mathrm{R}^{2} \%$ & $33.5^{* * *}$ & & $33.2^{* * *}$ & & $29.5^{* * *}$ & \\
\hline
\end{tabular}


Table 4

Regression Results of Using Civic Skills as A Predictor of Online Political Participation

\begin{tabular}{|c|c|c|c|c|c|c|}
\hline \multirow{3}{*}{ Independent variable } & \multicolumn{6}{|c|}{ Dependent variable } \\
\hline & \multicolumn{2}{|c|}{$\begin{array}{l}\text { Contacting } \\
\text { government online }\end{array}$} & \multicolumn{2}{|c|}{$\begin{array}{l}\text { Online monitoring } \\
\text { of public policies }\end{array}$} & \multicolumn{2}{|c|}{$\begin{array}{l}\text { Participation in } \\
\text { online protests }\end{array}$} \\
\hline & $\beta(S E)$ & $t$ & $\beta(S E)$ & $t$ & $\beta(S E)$ & $t$ \\
\hline \multicolumn{7}{|l|}{ Demographics } \\
\hline Gender & $.09(.08)$ & 1.13 & $.02(.08)$ & .27 & $.07(.08)$ & .91 \\
\hline Age & $-.19(.05)^{* * *}$ & -3.90 & $-.21(.05)^{* * *}$ & -4.32 & $-.40(.05)^{* * *}$ & -7.67 \\
\hline Occupation (have a job=1) & $.33(.10)^{* * *}$ & 3.21 & $.04(.10)$ & .41 & $.16(.11)$ & 1.41 \\
\hline Education & $-.07(.06)$ & -1.22 & $-.01(.06)$ & -.22 & $-.12(.06)^{*}$ & -2.01 \\
\hline Party affiliation $(\mathrm{CP}=1)$ & $-.04(.09)$ & -.43 & $.16(.09)$ & 1.77 & $.09(.10)$ & .95 \\
\hline Household income & $.10(.03)^{* * *}$ & 3.20 & $.05(.03)$ & 1.47 & $.07(.04)$ & 1.93 \\
\hline$\triangle \mathrm{R}^{2} \%$ & $10.1^{* * *}$ & & $8.6^{* * *}$ & & $9.5^{* * *}$ & \\
\hline \multicolumn{7}{|l|}{ Media use } \\
\hline Reading newspapers & $.00(.04)$ & .10 & $.00(.04)$ & .05 & $.01(.05)$ & .32 \\
\hline Watching TV & $-.00(.05)$ & -.06 & $.02(.05)$ & .45 & $-.01(.05)$ & -.11 \\
\hline Surfing on the Internet & $-.05(.05)$ & -1.12 & $.04(.05)$ & .94 & $-.06(.05)$ & -1.13 \\
\hline$\triangle \mathrm{R}^{2} \%$ & $6.0^{* * *}$ & & $4.8^{* * *}$ & & $5.3^{* * *}$ & \\
\hline Internal political efficacy & $.23(.05)^{* * *}$ & 4.62 & $.15(.05)^{* *}$ & 3.04 & $.21(.05)^{* * *}$ & 4.08 \\
\hline External political efficacy & $.05(.04)$ & 1.20 & $-.02(.04)$ & -.55 & $-.08(.04)$ & -1.83 \\
\hline$\triangle \mathrm{R}^{2} \%$ & $16.3^{* * *}$ & & $15.1^{* * *}$ & & $12.7^{* * *}$ & \\
\hline \multicolumn{7}{|l|}{ Resources } \\
\hline Civic skills & $.54(.04)^{* * *}$ & 15.10 & $.32(.04)^{* * *}$ & 8.80 & $.50(.04)^{* * *}$ & 12.91 \\
\hline Political interest & $.09(.05)$ & 1.66 & $.39(.05)^{* * *}$ & 7.12 & $.20(.06)^{* * *}$ & 3.43 \\
\hline \multicolumn{7}{|l|}{ Political interest } \\
\hline × Civic skills & $-.01(.02)$ & -.36 & $-.01(.02)$ & -.62 & $.01(.02)$ & .52 \\
\hline$\triangle \mathrm{R}^{2} \%$ & $12.6^{* * *}$ & & $9.1^{* * *}$ & & $11.7^{* * *}$ & \\
\hline Total Adj.R ${ }^{2} \%$ & $44.3^{* * *}$ & & $36.8^{* * *}$ & & $38.4^{* * *}$ & \\
\hline
\end{tabular}

Notes. All the coefficients are ordinary least squares standardized. ${ }^{*} p<.05,{ }^{* *} p<.01,{ }^{* * *} p<.001$. 